\title{
The Study of Spermatophyta Diversity Based on Taxonomy in Univet Bantara Sukoharjo
}

\author{
Anwari Adi Nugroho \\ Universitas Veteran Bangun Nusantara \\ Sukoharjo, Indonesia \\ bio_anwary@yahoo.com
}

\begin{abstract}
This study aimed to determine the diversity of seed plants (Spermatophyta) based on taxonomy in Univet Bantara Sukoharjo campus. This study type was an explorative descriptive. The study was carried out in 2017 at the Univet Bantara Sukoharjo campus. The method used was to census all spermatophyta plants in the campus environment. Data collection was done by observation, identification and documentation techniques. Data in the form of plant list were then identified in the laboratory to determine their taxonomy and grouped by divisions, subdivisions, class, subclass and family. The results showed that the number of plant species obtained showed a high diversity even though there were few families whose members were few. The number of spermatophyta species found was 106 species. Distribution of plants found were 2 plants of gymnosperms, 104 plants of angiosperms. Angiosperms amounted to 104 plants distributed into 39 plants monocotyledoneae class and 65 plants dicotyledoneae class (apetalae / monoclamidae as many as 18 plants, dialypetalae as many as 29 plants, sympetalae as many as 18 plants).
\end{abstract}

\section{Keywords - Diversity, Spermatophyta, Taxonomy}

\section{INTRODUCTION}

The largest biodiversity center in the world is in Indonesia, so Indonesia is called a megabiodiversity country which has a lot of genetic uniqueness, high diversity of species, ecosystems and endemies [1]. In addition, Indonesia is a vast and varied archipelagic country that lives in a variety of flora, fauna and microbes. Based on the biogeographic area profile, Indonesia has an important and strategic position in terms of the richness and diversity of plant species and its ecosystem [2]. Species diversity includes all species found on earth. Diversity is characterized by the many species that make up a community, the more the number of species, the higher the diversity [3]. The diversity of flowering plants in Indonesia constitutes $10 \%$ of the species of flowering plants in the world [4] or was the seventh largest country with species reaching 38,000 species, $55 \%$ are endemic or native to Indonesia [5]. High diversity and level of endemism make Indonesia a unique natural laboratory for tropical plants with various phenomena.

Whereas in terms of taxonomic diversity, the plant family that has the most species of number is the orchidaceae which was about 4,000 species. For woody plants, the dipterocarpaceae family has 386 species, 500 members of the myrtaceae family (eugenia) and moraceae (ficus) and 737 species of ericaceae family, including 287 rhododendrom species and 239 naccinium species [6]. Indonesia is also referred to as the Vavilov center, which was the center of the distribution of genetic diversity of cultivation / agricultural plants such as banana plants (Musa spp.) Nutmeg (Myristica fragrans), cloves (Syzygium aromaticum), durian (Durio spp.) and Nephelium spp [7].

Based on the results of the process of forming the land area of Indonesia as well as the results of Wallace and Weber's research, geologically, the distribution of flora (as well as fauna) in Indonesia is divided into 3 regions, namely Sundanese plain flora which includes Java, Sumatera, Kalimantan and Bali; Sahul plain flora which includes Papua and the surrounding small islands; the transitional flora (wallace area) which includes Sulawesi, Maluku, and Nusa Tenggara. Specifically for the Javanese flora, the characteristics of the plant are similar to the flora characteristics of the Asian continent, so it is often called the Asiatic flora. Flora in Java is dominated by plants with tree species from the Dipterocarpaceae tribe.

This diversity of resources has been partially utilized but human attention to its existence was still limited [8]. Only a small number of plant species that have known genetic resources information, especially for species that have been developed commercially. One group of high-level plants that live in Indonesia is spermatophyta. Spermatophyta (seed plants) is a plant with the characteristic of having an organ in the form of seeds. Seed plants can be divided into two divisions: gymnosperms (open seed plants) and angiosperms (closed seed plants). In addition, spermatophyta is a true cormus plant. Moringa plants are plants whose bodies can be clearly distinguished between true roots, stems and leaves.

University of Veteran Bangun Nusantara Sukoharjo is a college campus located in Sukoharjo Regency, Central Java. Various high-level plants grow around the campus, thus making the campus cooler and more beautiful. Some of these plants are intentionally planted as ornamental plants and there are wild plants. However, the number of species that live in the campus environment is not yet known in detail. In an effort to add information about plants that live in the campus environment, research on the diversity of spermatophyta (seed plants) has been carried out based on their taxonomy. Plants identification is an activity to reveal and establish the identity or identity of plants, more specifically, to determine the correct name of the plant and its proper place in the classification system. Classification is a way of sorting and classifying living things into certain groups or units. Identification and classification begins by observing morphological characteristics or characteristics of roots, tubers, rhizomes, stems, leaves, and other parts of plants in the species. The characters that appear can be used for the identification process. The plants identified are 
possible to be unknown to the world of science, so the determination of a new name, or level of taxon follows the rules of the KITT (International Code of Plant Nomenclature). Plants that have been identified can be identified using plant experts, herbaria, specimens, reference books, or keys to determination [9]. The purpose of this study was to determine the diversity of spermatophyta in the Univet Bantara Sukoharjo environment. Spermatophyta that grows on campus, were identified to determine the classification and then grouped according to taxonomy. The results of the research in the form of spermatophyta diversity based on taxonomy within the Veteran Bangun Nusantara University were used as one of the material materials in the module of high plant systematics for students of biological education [10].

\section{MATERIALS AND METHODS}

This type of research was descriptive qualitative. Qualitative descriptive research was carried out with the aim of describing, interpreting and describing the results of research that has been carried out systematically, factually, and accurately regarding the truth, facts and nature of seed plants (Spermathophyta). The study was conducted in AprilMay 2017 at the Veteran Bangun Nusantara University (Univet Bantara) Sukoharjo which was located at Jalan Letjend Sujono Humardani Number 1, Jombor, Bendosari, Sukoharjo. Research begans with data collection by means of literature review. After that a survey was conducted to find out the general description and determine the location observed. This study included all seed plants (spermatophyta) that live in the Univet Bantara Sukoharjo environment. The research used was census / chopping method for all types of spermatophyta plants that live in the Univet Bantara Sukoharjo environment. Data collection was carried out with exploration techniques, identification, literature review and documentation [11]. 1) exploration was carried out directly on site. Data collected in the form of plants complete with morphological and habitat data. These data were used to facilitate vegetation identification of plants so that clear data was obtained regarding the diversity of Spermatophyta plants in Univet Bantara Sukoharjo.

Observation and identification of plants was carried out directly on site. Several plant species that cannot be identified directly on site, were identified in a biological laboratory with the help of references and botanists (lecturers). Identification was carried out to determine the classification of the plant. Data collection was carried out with exploration techniques, identification, literature review and documentation [11]. 1) exploration was carried out directly on site. Data collected in the form of plants complete with morphological and habitat data. These data were used to facilitate vegetation identification of plants so that clear data is obtained regarding the diversity of Spermatophyta plants in Univet Bantara Sukoharjo. Data was analyzed using qualitative description that describes the results of identification in the form of various types of spermatophyta in terms of taxonomy.

\section{RESULTS AND DISCUSSION}

Univet Bantara Sukoharjo has an area of about 34,500 m2 (3.45 hectares) with an altitude of 100-110 MDPL. The Univet Bantara Sukoharjo campus environment consists of several buildings and surrounding areas overgrown with many plants. Plants that live in the campus environment have a natural life and some are intentionally planted. Plants intentionally planted affect the distribution of species and the number of individuals in the area. Distribution and number of individuals depends on the conditions, area, and area needs [12]. On campus, there are several plant species whose distribution is uneven and there are plants that dominate and spread in various areas. Various kinds of plants that grow mostly come from spermatophyta (seed plants). The results of identification of spermatophyta growing showed that there were 106 species of spermatophyta. Following are the results of research on the diversity of Spermatophyta plants (seed plants) on the campus environment.

TABLE 1. SPERMATOPHYTA DIVERSITY IN THE UNIVET BANTARA SUKOHARJO.

\begin{tabular}{|c|c|c|c|c|c|c|}
\hline \multirow{3}{*}{ No } & \multirow{3}{*}{ Name of Plants } & \multirow{3}{*}{ Gymnospermae } & \multicolumn{4}{|c|}{ Angiospermae } \\
\hline & & & \multirow[b]{2}{*}{ Monokotiledoneae } & \multicolumn{3}{|c|}{ Dikotilidoneae } \\
\hline & & & & $\begin{array}{c}\text { Apetalae } \\
\text { (monoclamidae) }\end{array}$ & Dialypetalae & Sympetalae \\
\hline 1 & Anthurium plowmanii & & Araceae & & & \\
\hline 2 & Rhoeo discolor & & Commelinaceae & & & \\
\hline 3 & Syzgium oelana & & & & Myrtaceae & \\
\hline 4 & Ageratum conyzoides & & & & & Asteraceae \\
\hline 6 & Mimosa pudica & & & & & Mimosaseae \\
\hline 7 & Jasminum sambac & & & & & Oleaceae \\
\hline 8 & Juniperu srigida & coniferales & & & & \\
\hline 9 & Kalanchoe pinnata & & & & Crassulaceae & \\
\hline 10 & Apium graveolens & & & & Zingiberaceae & \\
\hline 11 & Kaemteria galanga & & & & Zingiberaceae & \\
\hline 12 & Cupressus sempervirens & coniferales & & & & \\
\hline 13 & Carica papaya & & & & Caricaceae & \\
\hline 15 & Mangifera indica & & & & Anacardiaceae & \\
\hline 16 & Polianthus tuberosa & & & Cactaceae & & \\
\hline 17 & Leucanea leucocephala & & & & & mimosaceae \\
\hline 18 & Cajuput oil & & & & Myrtaceae & \\
\hline 19 & Musa paradisiaca & & Musaceae & & & \\
\hline 20 & Ceiba pentandra & & & & Bombacaceae & \\
\hline
\end{tabular}




\begin{tabular}{|c|c|c|c|c|c|c|}
\hline \multirow{3}{*}{ No } & \multirow{3}{*}{ Name of Plants } & \multirow{3}{*}{ Gymnospermae } & \multicolumn{4}{|c|}{ Angiospermae } \\
\hline & & & \multirow[b]{2}{*}{ Monokotiledoneae } & \multicolumn{3}{|c|}{ Dikotilidoneae } \\
\hline & & & & $\begin{array}{c}\text { Apetalae } \\
\text { (monoclamidae) }\end{array}$ & Dialypetalae & Sympetalae \\
\hline 21 & Casuarina equisentifolia & & & Casuarinaceae & & \\
\hline 22 & Livistonachinensis & & Arecacea & & & \\
\hline 23 & Cordyline frukticosa & & Agavaceae & & & \\
\hline 24 & Codiaeum variegatum & & & Euphorbiaceae & & \\
\hline 25 & Cordiaeum sp. & & & Euphorbiaceae & & \\
\hline 26 & Thyponium flagelliforme & & Aracaceae & & & \\
\hline 27 & Terminalia cattapa & & & & Combretaceae & \\
\hline 28 & Brassica orelacea var. italica & & & & Brasicaceae & \\
\hline 29 & Euphorbia milli & & & Euphorbiacae & & \\
\hline 30 & Syzygium aqueum & & & & Myrtaceae & \\
\hline 31 & Archraszapota & & & & & Sapotaceae \\
\hline 32 & Zingibe rOfficinale & & Zingiberaceae & & & \\
\hline 33 & Ocimumbasilicum & & & & & Lamiaceae \\
\hline 34 & Aloe vera & & Xanthorrhoeaceae & & & \\
\hline 35 & Cymbopogon citratus & & Poaceae & & & \\
\hline 36 & Capsicum frustescens & & & & & Solanaceae \\
\hline 37 & Sansevieria trifasciata Prain & & Agavaceae & & & \\
\hline 38 & Chrysalidocarpus lutescens & & Arecaceae & & & \\
\hline 39 & Ptychosperma macarthurii & & Arecaceae & & & \\
\hline 40 & Saraca indica & & & & Caesalpiniaceae & \\
\hline 41 & Bougenvillea & & & Nictaginaceae & & \\
\hline 42 & Zamiaculcas zamifolia & & & Moraceae & & \\
\hline 43 & Adenium obesum & & & & & Apocynaceae \\
\hline 44 & Ipomea cairica & & & & & Apocynaceae \\
\hline 45 & Ficus benjamina & & & Moraceae & & \\
\hline 46 & Cymbidium $s p$. & & Orchidaceae & & & \\
\hline 47 & Filicium sp. & & & & Sapindaceae & \\
\hline 48 & Dhryophloeus beguinii & & Arecaceae & & & \\
\hline 49 & Dimocarpus longanum & & & & Sapindaceae & \\
\hline 50 & Axonopus compressus & & Poaceae & & & \\
\hline 51 & Euphorbia hirta & & & & Euphorbiaceae & \\
\hline 52 & Zoysia japonica & & Poaceae & & & \\
\hline 53 & Chloris barbata & & Poaceae & & & \\
\hline 54 & Talinum paniculatum & & & & Portuacaceae & \\
\hline 55 & Veitchia merillii & & Arecaceae & & & \\
\hline 56 & Plumeria acuminata & & & & & Apocynaceae \\
\hline 57 & Chamaedorea seifrizli & & Arecaceae & & & \\
\hline 58 & Phyllanthus reticulatus & & & Euphorbiaceae & & \\
\hline 59 & Cyperus rotundus & & Cyperaceae & & & \\
\hline 60 & Schefflera grandiflora & & & & Araliaceae & \\
\hline 61 & Citrus sinensis & & & & Rutaceae & \\
\hline 62 & Pterocarpus indicus & & & & & Papilionaceae \\
\hline 63 & Dendrobium phalaenopsis & & Orchidaceae & & & \\
\hline 64 & Eragrotis amabilis & & Poaceae & & & \\
\hline 65 & Dactyloctenium aegyptium & & Poaceae & & & \\
\hline 66 & Sporobolus poiretii & & Poaceae & & & \\
\hline 67 & Polyalthia longifalia & & & & Annonaceae & \\
\hline 68 & Portulaca oleracea & & & Portulacaceae & & \\
\hline 69 & Dendrocnide moroides & & & & Urticaceae & \\
\hline 70 & Clorophytum comosum & & Antericaceae & & & \\
\hline 71 & Bidens pilosa & & & & & Asteraceae \\
\hline 72 & Terminalia mantaly & & & & Combretaceae & \\
\hline 73 & Dracaena fragrans & & Asparagaceae & & & \\
\hline 74 & Citrus hystrix & & & & Rutaceae & \\
\hline 75 & Clitoria ternatea & & & & & Papilionaceae \\
\hline 76 & Samanea saman & & & & & Mimosaceae \\
\hline 77 & Muntingia calabura & & & & Muntingiaceae & \\
\hline 78 & Manihot glaziovii & & & Euphorbiaceae & & \\
\hline 79 & Axonopus compressus & & Poaceae & & & \\
\hline 80 & Rosa sp & & & & Rosaceae & \\
\hline 81 & Sesbania grandiflra & & & Papilionaceae & & \\
\hline 82 & Arachnis flos aeris & & Orchidaceae & & & \\
\hline 83 & Nephellium lappaceum & & & Sapindaceae & & \\
\hline 84 & Psidium guajava & & Myrtaceae & & & \\
\hline 85 & Colocasia & & Araceae & & & \\
\hline 86 & Canna indica & & Canaceae & & & \\
\hline 87 & Averrhoa carambola & & & & Oxalidaceae & \\
\hline 88 & Tectona grandis & & & & Laminaceae & \\
\hline 89 & Nerium oleander & & & & Veregnaceae & \\
\hline 90 & Peperomia pellucida & & & Piperaceae & & \\
\hline 91 & Glyune max & & & Papilionaceae & & \\
\hline 92 & Eclipta prostrata & & & & & Asteraceae \\
\hline
\end{tabular}




\begin{tabular}{|c|c|c|c|c|c|c|}
\hline \multirow{3}{*}{ No } & \multirow{3}{*}{ Name of Plants } & \multirow{3}{*}{ Gymnospermae } & \multicolumn{4}{|c|}{ Angiospermae } \\
\hline & & & \multirow[b]{2}{*}{ Monokotiledoneae } & \multicolumn{3}{|c|}{ Dikotilidoneae } \\
\hline & & & & $\begin{array}{c}\text { Apetalae } \\
\text { (monoclamidae) }\end{array}$ & Dialypetalae & Sympetalae \\
\hline 93 & Phylantus nururi & & & Euporbiaceae & & \\
\hline 94 & Cynodon dactylon & & Poaceae & & & \\
\hline 95 & Amaranthus spinosus & & & Amarantaceae & & \\
\hline 96 & Dieffenbachia ambena & & Araceae & & & \\
\hline 97 & Aglonema cmutatum & & & & Araceae & \\
\hline 98 & Alternanthera brasilliana & & & Amaranthaceae & & \\
\hline 99 & Hedyotis crymbosa & & Poaceae & & & \\
\hline 100 & Eleusine indica & & Poaceae & & & \\
\hline 101 & Chentotheca lappacea & & Commelinaceae & & & \\
\hline 102 & Casuaring junghulni & & Casuarinaceae & & & \\
\hline 103 & Solanum ningrum & & & & & Solanaceae \\
\hline 104 & Vernnia cinerea & & & & & Asteraceae \\
\hline 105 & Isora $s p$ & & & & Rubiaceae & \\
\hline 106 & Dracaena reflexa & & Agavaceae & & & \\
\hline & Total & 2 & 39 & 18 & 29 & 18 \\
\hline
\end{tabular}

Data on the diversity of spermatophyta plants in the Univet Bantara Sukoharjo campus showed that the number of plant species obtained showed a high diversity even though there were few families whose members were few. In detail the plants found included 104 species of angiospermae with details of dicotyledoneae (magnoliopsida) had the highest number of 65 species, while monocotyledoneae were 39 species. The gymnosspermae group was 2 species. Plants need certain conditions to grow and develop properly. The existence of plants especially angiosperms is strongly influenced by abiotic factors. Abiotic factors in this study are air temperature and soil $\mathrm{pH}$. The temperature in the campus environment ranges from $25^{\circ}-30^{\circ} \mathrm{C}$. The temperature is included in the warm category. High plants including angiosperms can grow optimally at temperatures of $10-38^{\circ} \mathrm{C}$. Generally plants do not grow at temperatures below $0^{\circ} \mathrm{C}$ and above $45^{\circ} \mathrm{C}$. The optimal temperature causes the photosynthetic process of angiosperm to take place smoothly. Air temperature is a component of microclimate that affects growth and creates optimal environmental conditions for plants. Growth increases if temperature increases and humidity decreases [13]. Soil temperature was influenced by air temperature, the intensity of sunlight entering the soil, and water in the soil [14]. Plants have an important role in controlling environmental temperature. Plants control environmental temperature through physiological processes, namely transpiration. Diverse plants, the plant canopy system will stimulate an increase in the rate of transpiration (especially to maintain plant temperature stability). The existence of plants is also able to absorb solar radiation, especially the role of tree shoots. Solar radiation is absorbed by the leaves of the canopy compiler as an energy source for photosynthesis [12]. The diversity of species that constitute plant communities in one place was also influenced by climate [15]. The Univet Bantara Sukoharjo campus is in a tropical climate, in the tropics has a more stable climate and has a higher diversity of species than in temperate and polar regions. In addition abiotic measurements are also carried out on soil $\mathrm{pH}$. Soil $\mathrm{pH}$ in the campus environment ranges from 5-7. This shows that the soil tends to be neutral towards the acid. The effect of $\mathrm{pH}$ on nutrient uptake and growth includes the effects of toxic substances and nutrient moisture [16].

Plant diversity is not only based on the number of species found but also the distribution of their families. The number of families found in the Bantara Sukoharjo Univet amounted to 48 among others poaceae, euphorbiacae, arecaceae, araceae, papilionaceae, myrtaceae, asteraceae, zingiberaceae, agavaceae, apocynaceae, orchidaceae, sapindaceae, mimosaceae, lamiaceae, solanaceae, moraceae, portuacaceae, rutaceae, amarantaceae, commelinaceae, casuarinaceae, combretaceae, brasicaceae, sapotaceae, xanthorrhoeaceae, caesalpiniaceae, nictaginaceae, cyperaceae, araliaceae, annonaceae, urticaceae, antericaceae, combretaceae, asparagaceae, muntingiaceae, rosaceae, canaceae, oxalidaceae, veregnaceae, piperaceae, rubiaceae, oleaceae, crassulaceae, caricaceae, anacardiaceae, cactaceae, musaceae, and bombacaceae. Here is a diagram of the distribution of families from the angiosperms found in Univet Bantara Sukoharjo. 


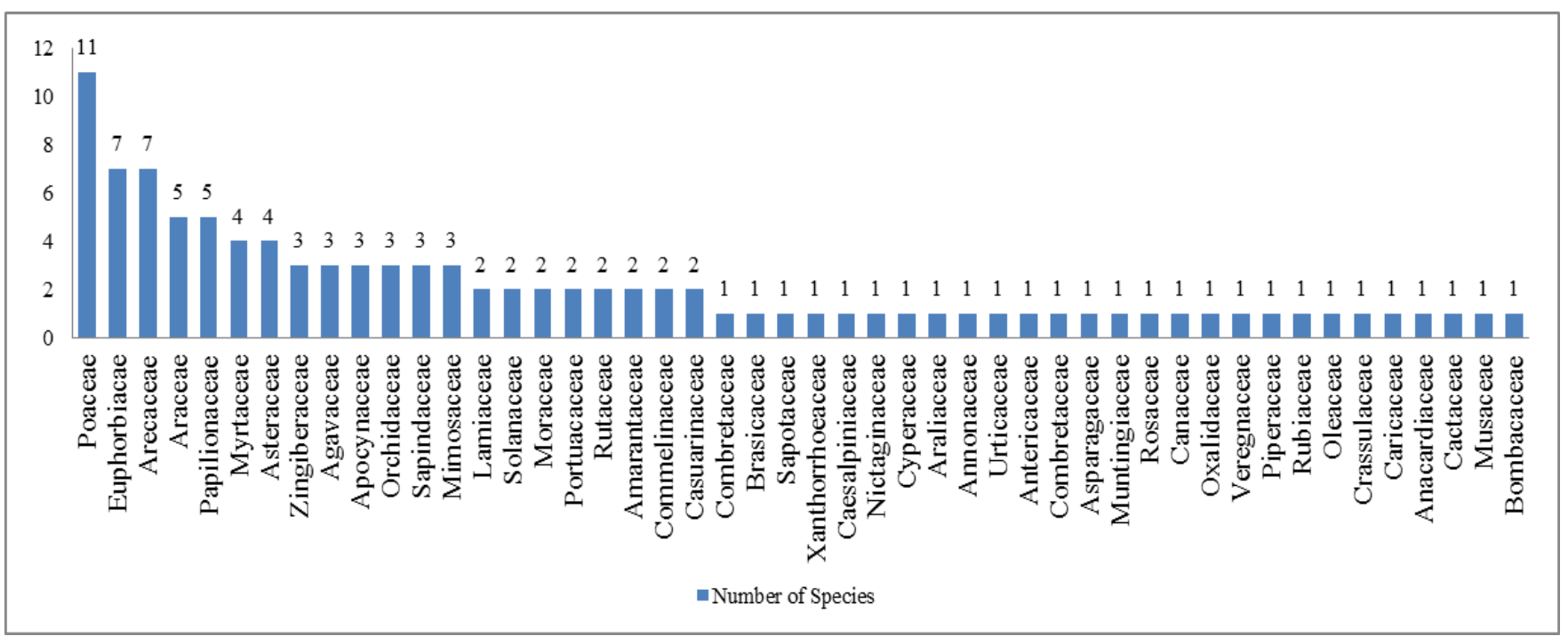

Figure 1. Family Distribution in Angiosperms

Most families are poaceae / graminae (grasses) with 11 species. These families were found on campus because the Poaceae family has microscopic sized seeds that were easily carried by the wind, have high adaptability, very wide distribution, and were able to grow both on dry and flooded land [17]. The existence of a plant is also affected by minerals. If the minerals needed support this type will be superior and more widely found [18]. Grass plants have a role to play in maintaining the balance of the ecosystem, strengthening the structure of the soil, helping to withstand falling water directly, and inhibiting or preventing erosion that takes place quickly. Grass plants can also prevent the fall of rainwater directly and encourage the development of soil biota that can improve the physical and chemical properties of the soil and play a role in increasing soil organic matter. The gymnospermae group only found 1 order with a total of 2 species, namely Juniperu srigida and Cupressus sempervirens. Gymnosperms were rarely found in low-lying areas and most plants in the highlands with low temperatures. Gymnosperms that grow on campus are plants that are intentionally planted as ornamental plants.

\section{CONCLUSION}

The study of spermatophyta diversity based on taxonomy in the Univet Bantara Sukoharjo campus environment showed that the number of plant species obtained shows a high diversity even though there were few families whose members are few. The number of spermatophyta species found was 106 species. Plants of the angiosperm group as many as 104 species with details of dicotyledoneae (magnoliopsida) had the highest number of 65 species, while the monocotyledoneae group were 39 species. The gymnossperma group was 2 species.

\section{REFERENCES}

11] Sutoyo, "Keanekaragaman hayati Indonesia. Buana Sains", Buana Sains, Vol. 10, pp. 101-106, 2016

[2] K. Triyono, "Keanekaragaman Hayati Dalam Menunjang Ketahanan Pangan", INNOFARM : Jurnal Inovasi Pertanian, vol. 11, pp. 12-22, 2013
[3] S. Heddy, M. Kurniati, Prinsip-prinsip Dasar Ekologi: Suatu Bahasan Tentang Kaidah Ekologi dan Penerapannya, Jakarta: PT Raja Grafindo Persada, 1996.

[4] S. Soedradjad, Lingkungan Hidup (suatu Pengantar), Jakarta: Universitas Indonesia Press, 1999.

[5] Bappenas, Indonesian Biodiversity Strategy and Action Plan, Jakarta: Dokumen Nasional Bappenas, 2003.

[6] T.C. Whitmore, Tropical Rain Forest of the Far East (revised ed.), Clarendon Press, Oxford. 1985.

[7] C. Kusmana, and A. Hikmat, "Keanekaragaman Hayati Flora di Indonesia. Jurnal Pengelolaan Sumberdaya Alam dan Lingkungan", vol. 5, pp. 187-198. 2015.

[8] Irwanto, Perspektif silvika dalam keanekaragaman hayati dan silvikultur. http://irwantoshut.com/, accessed on 10 September 2018, 2006.

[9] G. Tjitrosoepomo, Taksonomi Tumbuhan, Yogyakarta: Gadjah Mada University Press, 2009.

[10] A.A. Nugroho, and S. Subiyantoro, "Pengembangan Modul Sistematika Tumbuhan Tinggi Berbasis Guided Discovery untuk Mengembangkan Kemampuan Berpikir Kritis Mahasiswa Pendidikan Biologi”. BIO-PEDAGOGI, vol. 6, pp. 19-24, 2017.

[11] I. Aryani, "The Study of Spermatophyte Diversity at Hills Tlogodlingo, Tawangmangu, Karanganyar District”, Proceeding Biology Education Conference, vol. 14, pp. 109-113, 2017.

[12] I. Qomah, S.A. Hariani, and S. Murdiyah, "Identifikasi Tumbuhan Berbiji (Spermatophyta) di Lingkungan Kampus Universitas Jember", Bioedukasi, vol. 13, pp. 13-20, 2015.

[13] Widiningsih, Evaluasi Lahan, Malang: Fakultas Pertanian Unibraw, 1985.

[14] A.G. Kartasapoetra,), Pengaruh Iklim Terhadap Tanah dan Tanaman (Edisi Revisi), Jakarta: Bumi Aksara, 2006.

[15] E.P. Odum, Dasar-dasar Ekologi. Tjahjono Samingan's translation. Third Edition, Yogyakarta: Gadjah Mada University Press, 1993.

[16] I. Soerianegara, and A. Indrawan, Ekologi Hutan Indonesia. Bogor: Departemen Manajemen Hutan Fakultas Kehutanan IPB, 1988.

[17] H.R. Rukmana, and U.S. Saputra, Gulma dan Tehnik Pengendalian, Jakarta : Kanisius, 1999

[18] E.S. Syafei, Pengantar Ekologi Tumbuhan, ITB: Bandung, 1990. 